$1-1-1965$

\title{
Promotion of nursery products : effects on sales and consumer attitudes
}

Robert L. Jack

Follow this and additional works at: https://researchrepository.wvu.edu/ wv_agricultural_and_forestry_experiment_station_bulletins

\section{Digital Commons Citation}

Jack, Robert L., "Promotion of nursery products : effects on sales and consumer attitudes" (1965). West Virginia Agricultural and Forestry Experiment Station Bulletins. 510.

https://researchrepository.wvu.edu/wv_agricultural_and_forestry_experiment_station_bulletins/474 @ WVU. It has been accepted for inclusion in West Virginia Agricultural and Forestry Experiment Station Bulletins by an authorized administrator of The Research Repository @ WVU. For more information, please contact ian.harmon@mail.wvu.edu. 
Digitized by the Internet Archive in 2010 with funding from

Lyrasis Members and Sloan Foundation 


\begin{abstract}
AUTHOR
Author of Promotion of Nursery Products: Effects on Sales and Consumer Attitudes is Robert L. Jack, Assistant Agricultural Economist in the Agricultural Experiment Station and Assistant Professor of Consumer Economics in the College of Agriculture, Forestry, and Home Economics.
\end{abstract}

This report is a Nortleast regional publication. It is based on a cooperative study which was part of a Northeast Regional Project, N.E.M.-15, "Structure and Development of the Retail Market for Ornamental Nursery Products." The agricultural experiment stations of Massachusetts, New York, Pennsy.lvania, and West Virginia cooperated in obtaining the data used. The study was financed, in part, by Regional Research Fund, Hatch Act, as amended August 11, 1955.

West Virghia Uinersity

Agricultural Experinient Station

College of Agricllture, Forestry, and Home Economics

A. H. Vaxlandivghair, Director

MIORGANTOWN 


\section{PROMOTION OF NURSERY PRODUCTS: Effects on Sales and Consumer Attitudes}

\section{Northeast Regional Research Publication}

by

The Technical Committee of the Northeast Regional

Research Project, N.E.M.-15, "Structure and Development of the Retail Market for Ornamental Nursery Products"

\section{Administrative Advisor}

Joseph F. Metz, Jr.

Cornell University Agricultural

Experiment Station

\section{Technical Committee Members}

Maurice Baker

Clare A. Becker

John P. H. Brand

William H. Drew

Dana C. Goodrich, Jr.

New Hampshire Agricultural Experiment Station

Cornell University Agricultural

Experiment Station

Robert L. Jack

Elmar Jarvesoo

Roger W. Pease (until 1963)

West Virginia Agricultural Experiment Station

Massachusetts Agricultural Experiment Station

West Virginia Agricultural

Experiment Station

Raymond C. Smith

\section{Cooperating U.S.D.A. Members}

Roscoe J. Saville

Robert Fry
CSRS, Washington, D.C.

ERS, Washington, D.C. 



\section{Contents}

SUMMARY AND CONCLUSIONS $\ldots \ldots \ldots \ldots \ldots \ldots \ldots$

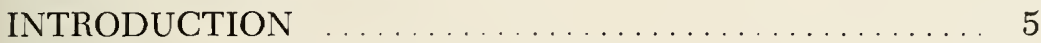

PURPOSE .............................. 5

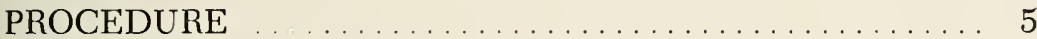

INQUIRIES RECEIVED $\ldots \ldots \ldots \ldots \ldots \ldots \ldots \ldots \ldots \ldots$

SALES RESPONSE ....................... 8

COSTS AND RETURNS ..................... 10

FOLLOW-UP INTERVIEWS . . . . . . . . . . . . 11

THEORETICAL IMPLICATIONS $\ldots \ldots \ldots \ldots \ldots \ldots \ldots \ldots$

LITERATURE CITED . . . . . . . . . . . . . . . 15 


\section{Summary and Conclusions}

ПHE purpose of this study was twofold. (1) To determine if dollar states by unotional program which offered gratuitous information and service to consumers. (2) To determine if a promotional program could produce a significant change in consumer attitudes toward landscaping and toward nurseries as a supply source for ornamental products.

Of the 3,499 homeowners who received the brochure treatment, 66 , or 1.89 per cent, made inquiries about gratuitous information and service by returning post cards, by telephone, or by personal visits to the nurseries. The promotional program was most effective in stimulating inquiries when directed at relatively unplanted homes ${ }^{*}$ located in nonmetropolitan cities where economic conditions were not depressive as compared to surromding areas.

Except for one nursery, the number of purchases per one hundred lomes was larger in experimental than control areas. However, average expenditure per purchase was larger for control than for experimental areas for five of the six nurseries, and the value of purchases per one hundred homes did not show any consistent pattern of behavior.

Cost of material, labor, and transportation necessary to offer the promotional program to one hundred homeowners was approximately \$33.5S. Except for Mest Virginia's City B and Pennsylvania's Nursery I the cost of the promotional program was greater than the net gain in value of sales. However, this study did not determine the influence that the promotional program had on future sales.

Follow-up interviews indicated that brochure recipients felt the in formation in the brochure was desirable. However, the promotiona program did not produce a significant change in the attitudes of home owners toward landscaping or toward nurseries as a source for orna mental products.

Data obtained in this and other studies suggest that the ornamenta market is restricted in size, has few sellers relative to number of potentia buyers, sells products which are differentiated in the consumers' minds and uses non-price competition. These characteristics are similar to those found in an oligopolistic market.

- See footnote, p. 8. 


\section{PROMOTION OF NURSERY PRODUCTS: Effects on Sales and Consumer Attitudes}

\section{Introduction}

TALUE of ornamental plants at wholesale prices has been increasing rapidly in the northeastern region ${ }^{1}$ of the United States. However, he rate of increase for the region from 1949 to 1959, [107 per cent] has agged slightly behind that of the United States [118 per cent] (1).

Ornamental nursery sales contributed $\$ 31.3$ million to the economy of the northeastern region in 1959 (1). As a general rule, these ornanentals were produced by small-scale growers not financially able to support research which would help solve producer marketing problems.

Studies by Pease (2) and by Kivlin and Becker (3) indicated that consumers desire information and service which will aid them in selectng proper plants, planting, controlling diseases and insects, and making andscape sketches. Based upon these findings it was hypothesized that iales of ornamentals could be increased by providing consumers with gratuitous information and service which would help solve problems associated with home landscaping and growing ornamentals around the nome.

\section{Purpose}

The purpose of this study was twofold. (1) To determine if dollar iales of ornamental products could be increased in the northeastern itates by using a promotional program which offered gratuitous informaion and service to consumers. (2) To determine if a promotional prosram could produce a significant change in consumer attitudes toward andscaping and toward nurseries as a supply source for ornamental roducts.

\section{Procedure}

All agricultural experiment stations particpating in the project ffered gratuitous information and service ${ }^{2}$ to help consumers solve prob-

${ }^{1}$ Northeast, as used in this study, includes Maine, Vermont, New Hampshire, Jonnecticut, Massachusetts, Rhode Island, Delaware, New York, Maryland, New lersey, Pennsylvania, and West Virginia.

${ }^{2}$ Cooperating nurseries distributed brochures containing information on types of lants, planting, disease and insect control, pruning, and plant characteristics. The rochure also offered free landscape sketching service to homeorners. 
lems connected with growing ornamentals. However, all stations did not use exactly the same procedure. In general, participating stations used the following procedure.

For the spring selling season of 1961 each station selected one or more nurserymen to cooperate in the project. Cooperating nurserymen and experiment station project leaders selected an area or areas where single-family dwellings were prevalent and conveniently located to cooperating nurserymen. The areas selected were also ones which the nurserymen felt had potential for increasing ornamental sales (i.e., generally newer homes with only partially landscaped grounds). These areas were divided into test areas having approximately the same number of homes, but the test areas were stratified by age and value of homes, degree of planting around the homes, economic conditions of the area, and other observable socioeconomic factors. Each of the test areas was divided into an experimental area and a control area which appeared to be matched for age and value of homes, degree of ornamental planting around homes, and other observable socioeconomic factors. A buffer zone, usually one block wide, was used to prevent carryover effect from experimental to control areas.

In February and March, shortly before the spring planting season brochures offering gratuitous information and service were distributec (as a treatment) to all owner-occupied homes located in the experi mental areas only. At the same time, addresses and, where possible names of recipients were recorded for future use in measuring the effec of the promotional program.

The brochures were designed to focus recipients' attention on th importance of good landscaping and to offer information and advice on problems commonly associated with home landscaping. The brochure gave the name and address of the cooperating nurseryman who woul supply free information in the form of pamphlets or advice and service $i$ the form of landscaping sketches. Recipients of the brochures wh desired information and free service were required to return the enclosec stamped post card, or telephone the nursery, or request in person th free informative literature and service before a specified date, usuall April 1, or before appointment books were filled.

Cooperating nurserymen recorded names and addresses of in dividuals who made inquiries about or actually made use of the fre literature and service. Names and addresses of those making purchase during the experimental period were also recorded. These names an addresses were compared with those obtained when brochures wes distributed. Matching the data from experimental areas with those ol tained from the control areas enabled researchers to measure the effe of the promotional program. 
After the 1961 planting season was over, a sample of homeowners living in experimental and control areas was personally interviewed to obtain data on age of home, value of home, expenditures for ornamentals, occupation of homeowner, recall of promotional program, and attitude toward nurserymen.

\section{Inquiries Received}

Of the 3,499 homeowners who received the brochures, 66 , or 1.9 per cent, made inquiries by use of the enclosed post cards, by telephone, or by personal visits to cooperating nurseries. The proportion of brochurereceiving homeowners who made inquiries at cooperating nurseries ranged from .85 per cent in Pennsylvania to 9.30 per cent in West Virginia (Table 1).

Although the number of inquiries, as a response to the promotional brochures, for each station and for the entire project was small, the data show a new dimension when distributed according to locational characteristics of the various nurseries involved.

Pennsylvania's Nursery I, located in open country surrounded by small towns, received six inquiries ( 1.2 per cent) from 500 brochure recipients. Nurseries II and III, located in medium-size cities, received ten inquiries ( 1 per cent) from 1,000 brochure recipients, and Nursery IV, located in the suburb of a large metropolis, received only one inquiry (.2 per cent) from 500 recipients. In other words, Nursery I received six times as many inquiries per one hundred recipients as did Nursery IV (Table 2).

Cooperating nurseries in New York and Massachusetts received almost four times as many inquiries from each one hundred "Relatively

Table 1. Inquiries Received by Cooperating Nurserymen for Gratuitous Information and Service

\begin{tabular}{c|c|c|c}
\hline \multicolumn{1}{c|}{ State } & $\begin{array}{c}\text { Households } \\
\text { Receiving Brochures }\end{array}$ & \multicolumn{2}{|c}{ Inquiries Received } \\
\cline { 2 - 4 } & $($ Number $)$ & $($ Number $)$ & $($ Per Cent $)$ \\
Pennsylvania & 2,000 & $17^{*}$ & .85 \\
Massachusetts & 800 & 23 & 2.88 \\
New York & 484 & 6 & 1.24 \\
West Virginia & 215 & 20 & 9.30 \\
Total & 3,499 & 66 & 1.89 \\
\hline
\end{tabular}

* Represents the number of post cards returned to the nursery. Information on the number of telephone inquiries or nursery visits by homeowners receiving the brochure was not obtained by Pennsylvania. 
Table 2. Inquiries Received, Distributed by State and Characteristics of Experimental Area

\begin{tabular}{|c|c|c|c|}
\hline \multirow{2}{*}{$\begin{array}{c}\text { Characteristics of } \\
\text { Experimental Areas } \\
\text { by States }\end{array}$} & \multirow{2}{*}{$\begin{array}{c}\text { Households } \\
\text { Receiving } \\
\text { Brochures }\end{array}$} & \multicolumn{2}{|c|}{ Inquiries Received } \\
\hline & & (Number) & (Per Cent) \\
\hline Pennsylvania & & & \\
\hline Nursery $\mathbf{I}^{\circ} \ldots \ldots$ & 500 & 6 & 1.20 \\
\hline Nurseries II \& $111^{\circ}$ & 1,000 & 10 & 1.00 \\
\hline Nursery IV $\dagger \ldots \ldots$ & 500 & 1 & .20 \\
\hline Massachusetts and New York & & & \\
\hline Relatively Planted Homes . & 400 & 3 & .75 \\
\hline Relatively Unplanted Homes & 884 & 26 & 2.91 \\
\hline West Virginia & & & \\
\hline City $\mathrm{A} \dagger \dagger$ & 107 & 4 & 3.74 \\
\hline City B & 108 & 16 & 14.81 \\
\hline
\end{tabular}

${ }^{\circ}$ Nursery located in open country.

* Nurseries located in medium-size cities.

† Nursery located in suburb of large metropolis.

t†City A was characterized by an abnormally high rate of unemployment and by uncertainty concerning future employment. In other words, City A was economically depressed relative to City B.

Planted Homes." In West Virginia response to the brochure treatment was only one-fourth as great in the economically-depressed City A as ir City B, which was in better economic condition (Table 2 ).

The above findings suggest that providing gratuitous information and service would be most effective in stimulating inquiries when direct ed at relatively umplanted homes ${ }^{*}$ located in non-metropolitan citie: where economic conditions are not depressed relative to surrounding areas.

\section{Sales Response}

The mailing list compiled when brochures were distributed wa compared with the list of individuals making ornamental purchases a cooperating nurseries in 1961. This comparison showed the effect of th promotional program on increasing ornamental sales to be small ( Tabl 3). Except for Pennsylvania's Nursery IV, the number of purchases pe one hundred homes was larger for experimental areas than for contro areas. Value of purchases per one hundred homes was not consistentl larger in experimental than control areas. And for four of the six nur: eries, the average expenditure per purchase was larger for control tha for experimental areas (Table 3 ).

"Relatively Planted Homes refers to homes with well landscaped ground Relatively Unplanted Homes refers to homes with only partially landscaped ground 
Table 3. Distribution of Ornamental Purchases Per One Hundred Homes, and Average Expenditure Per Purchase by Location of Experimental and Control Areas, West Virginia and Pennsylvania, $1961^{*}$

\begin{tabular}{|c|c|c|c|}
\hline $\begin{array}{c}\text { State and Location } \\
\text { of Areas }\end{array}$ & $\begin{array}{c}\text { Purchases } \\
\text { Per One } \\
\text { Hundred } \\
\text { Homes }\end{array}$ & $\begin{array}{c}\text { Value of } \\
\text { Purchases } \\
\text { Per One } \\
\text { Hundred } \\
\text { Homes }\end{array}$ & $\begin{array}{c}\text { Average } \\
\text { Expenditure } \\
\text { Per Purchase }\end{array}$ \\
\hline $\begin{array}{c}\text { West Virginia } \\
\text { City } A^{*}\end{array}$ & (Number) & (Dollars) & (Dollars) \\
\hline Experimental Area & 8.4 & 55.00 & 6.55 \\
\hline Control & 6.9 & 57.00 & 8.26 \\
\hline City B & & & \\
\hline Experimental Area & 29.4 & 205.00 & 6.97 \\
\hline Control ........ & 6.0 & 73.00 & 12.17 \\
\hline Pennsylvania & & & \\
\hline $\begin{array}{l}\text { Nursery } I \dot{\dagger} \\
\text { Experimental Area } \\
\text { Control }\end{array}$ & $\begin{array}{l}1.6 \\
1.2\end{array}$ & $\begin{array}{r}128.00 \\
27.00\end{array}$ & $\begin{array}{l}80.00 \\
22.50\end{array}$ \\
\hline Nursery $\mathrm{II} \dagger \dagger$ & & & \\
\hline Experimental Area & 4.2 & 102.00 & 24.29 \\
\hline Control $\ldots \ldots \ldots$ & 2.6 & 136.00 & 52.31 \\
\hline Nursery $111 \div \dagger$ & & & \\
\hline Experimental Area & 2.4 & 250.00 & 104.17 \\
\hline Control $\ldots \ldots \ldots$ & 1.4 & 240.00 & 171.43 \\
\hline Nursery IV§ & & & \\
\hline Experimental Area & 2.4 & 255.00 & 106.25 \\
\hline Control & 2.8 & 639.00 & 228.21 \\
\hline
\end{tabular}

*Data not available for New York and Massachusetts.

* City A was characterized by an abnormally high rate of unemployment and by uncertainty concerning future employment. In other words, City A was economically depressed relative to City $\mathrm{B}$.

$\dagger$ Nursery located in open country.

$\dagger$ Turseries located in medium-size cities.

$\S$ Nursery located in suburb of large metropolis.

Data in Table 3 indicate that a promotional program offering gratuitous information and service is more effective in increasing the number of purchases and value of purchases per one hundred homes when directed at non-metropolitan areas which are not as economically depressed as surrounding areas. The larger number of small purchases in the experimental area suggests that the brochures induced homeowners to visit the nursery and make small purchases. Some of these homeowners might become future customers at the nursery. ${ }^{3}$

${ }^{3}$ The small number of responses generated by the offering of free information and service makes it difficult to draw firm conclusions from the findings of this study. However, the methodology used in the study should be helpful to other researchers. And the findings should have enough validity to be valuable to nurserymen. 


\section{Costs and Returns}

Although a promotional program may increase the number of purchases and value of purchases, nurserymen want to know if the increase in sales is at least large enough to cover costs of the promotional program.

Table 4 indicates that material, labor, and transportation for such a program would cost $\$ 33.5 \$$ for one hundred homes.

Table 4. Cost of Material, Labor, and Traxsportation Necessary to Offer tile Informational and Service Program to One Hundred Ho\rES

\begin{tabular}{|c|c|c|}
\hline Type of Cost & Unit Cost & $\begin{array}{l}\text { Total Cost } \\
\text { Per Hundred }\end{array}$ \\
\hline & (Dollars) & (Dollars) \\
\hline Informative Brochure ${ }^{\circ}$ & .0385 & 3.85 \\
\hline Return Post Cards ${ }^{\circ}$ & .0161 & 1.61 \\
\hline Stamp for Return Post Card & .0400 & $4.00 \div \div$ \\
\hline $\begin{array}{l}\text { Addressing envelopes, selecting homes, } \\
\text { and compiling mailing list }{ }^{\circ}\end{array}$ & .0755 & 7.55 \\
\hline Delivering Brochure & & \\
\hline (.7 minutes each $x \$ 1.25$ per hour $) \dagger$ & .1457 & 14.57 \\
\hline $\begin{array}{l}\text { Travel } \\
\qquad(2 \text { mile per brochure } \times \$ .10\end{array}$ & & \\
\hline per mile) $\div$ & .0200 & 2.00 \\
\hline Total Cost & .3358 & 33.58 \\
\hline
\end{tabular}

"Eyerly, Raymond Wemer, Development of and Consumer Responses to an Informational Merchandising Technique for Ornamental Nursery Products. (Unpublished Master's Thesis. The Pennsylvania State University, Department of Agricultural Economics and Rural Sociology, 1963.)

${ }^{\circ}$ Computed from records kept by Pennsylvania while working on the project

$\doteqdot$ Time used and miles driven per brochure delivery were computed from record kept by Pennsylvania while working on the project. The $\$ 1.25$ per hour and $\$ .16$ per mile are the rates at which these services are normally paid.

$\dagger \rightarrow$ Cash cost could be reduced by using a return-postage permit.

In other words, the program would be profitable only if the value of sales per one hundred homes in experimental areas would be at leas $\$ 33.59$ greater than sales in control areas.

The differences between value of purchases per one hundred home for related experimental and control plots (Table 3) show that the pro gram was profitable only for West Virginia's City B and Pennsylvania' Nursery I. For City A and Nurseries II, III, and IV, the cost of the pro gram was greater than the net gain in value of purchases per on hundred homes. 
Data presented are only for purchases made in the spring and summer of 1961. It is possible that the type of promotional program used in this study may have a "sleeper effect" which might influence ornamental sales in the future. ${ }^{*}$ For five of the six nurseries the number of purchases per one hundred homes increased and the average expenditure per purchase decreased. This suggests that the promotional program induced brochure recipients to visit nurseries and make a larger number of small purchases (Table 3). Although brochure recipients had smaller average expenditures per purchase, these customers may become steady patrons of the nursery in the future. In this case, the cost of the promotional program should be spread over several years instead of just one year.

\section{Follow-Up Interviews}

After the 1961 spring planting season, personal interviews were conducted with approximately 30 per cent of the homeowners residing in experimental and control areas. The purpose of these interviews was to determine if attitudes toward nurseries, especially cooperating nurseries, as a supply source for ornamental plants had changed as a result of the promotional program. Socioeconomic data which could be used to compare homeowners living in experimental and control areas were also obtained by the interviewers.

Statistical analysis of the data indicated that in most cases the related experimental and control areas were not significantly different in value of homes, age of homes, occupations, family incomes, age of respondents, and other socioeconomic variables. ${ }^{5}$

Approximately 40 per cent of the brochure recipients recalled receiving the brochures. Furthermore, many of them also were able to recall titles of brochures and subject matter contained. About 65 per cent of the homeowners who recalled receiving the brochures felt that the brochures were useful.

There was no statistically significant difference between number of planned future ornamental purchases that would be made at cooperating nurseries by homeowners in experimental and control areas. Moreover, there was no significant difference between the number of homeowners in experimental and control areas who recommended cooperating nurseries to neighbors or friends as desirable sources of ornamental plants.

${ }^{4}$ The Pennsylvania State University analyzed 1961 Fall Sales, 1962 Spring Sales, and Repeat Sales. Evidence that the promotional program may have a "sleeper effect" on future ornamental sales was inconclusive.

${ }^{5}$ The .05 level was used to determine statistical significance. 
These findings indicate that the promotional program provided gratuitous information and service which recipients could recall and which they felt was useful; however, the program did not prove to be effective in producing a significant difference in attitudes toward landscaping and toward nurseries as a supply source for ornamental plants.

\section{Theoretical Implications}

The small response to the promotional program used in this study may be partially explained by the market structure which the data suggest exists in the ornamental industry.

Economic theory admits that various forms of market structure exist in the real world. When these market forms are ordered on a scale by the amount of control sellers have over supply and price, one finds pure competition and pure monopoly on opposite ends of the scale. With pure competition we find many sellers marketing products which are alike. None of the large number of sellers are large enough to influence supply or price of the product being sold in the market. When a monopoly market structure exists, we find one seller marketing a product for which there is no good substitute. Since there is only one seller in the market, he has a great influence on market supply and price. The forms of market structure existing between these two extremes of pure competition and pure monopoly have varying degrees of competition. A movement from pure competition to pure monopoly decreases the degree of competition existing in the market by giving the seller greater control over the supply and price of the product being sold.

In the ornamental industry there are few sellers relative to the number of potential buyers of ornamental products. Although the ornamental products may be exactly alike, the consumer usually sees the two products as being different because of the convenient location of selling firms, services offered with products, personality of the nurseryman, package, container, or consumers' tastes and preferences. Since the ratio of ornamental sellers to potential ornamental buyers is small and since ornamental products are differentiated in the consumers' minds, the ornamental industry may be considered as having a market structure which falls on the market structure scale somewhere between pure competition and pure monopoly. This position on the scale gives the seller more control over market supply and price than he would have in a pure competitive market but less control than he would have in a pure monopoly situation.

Two types of market structure, monopolistic competition and oligopoly, fall on the market structure scale between pure competition and pure monopoly. In the monopolistic competition situation it is 
assumed that the products are differentiated in the consumers' minds and that a large number of sellers exist, none of which is large enough to influence market supply or price.

The first assumption appears to be fulfilled by the ornamental market since the products are differentiated in the consumers' minds. An indication of ornamental product differentiation is found in the following statement. After analyzing consumer attitudes toward various sources of ornamentals, Pease said: "The analysis indicates that homeowners usually prefer to purchase ornamentals at nurseries rather than at chain stores" (2). Although this statement indicates that consumers differentiate sources of ornamental products, it also suggests indirectly that consumers differentiate ornamental products.

The second assumption of a large number of sellers of which none is large enough to influence market supply or price does not appear to be realistic for the ornamental market. Although improved transportation facilities and packaging have increased the size of the market area for ornamentals, the climatic requirements, bulkiness, and weight of most ornamental plants still tend to limit the size of the market area for ornamental plants. Following are some statements which suggest that the above market restrictions exist. One study of ornamental markets in West Virginia reports that, "Plants usually show complete winter hardiness at the nursery, but when grown at different elevations and in more rigorous climates, they may not survive" (4). A study of the ornamental supply jources for New York retail nursery outlets found that: "The major sources of supply of out of state nursery stock are New Jersey, Connectizut, Ohio, Pennsylvania, and Delaware" (5). Notice that three of these itates border New York, while Ohio and Delaware are nearby.

If the markets for ornamentals tend to be limited, as suggested tbove, we find ourselves in a localized market where products are diferentiated in the consumers' minds and are sold by a few sellers relative o the number of potential buyers. In a market situation of this type the iellers become major competitors with one another and the marketing ractices and policies of any one seller can affect the sales of other iellers in the market. In a market of this type sellers use various forms of non-price competition. That is, a seller attempting to increase sales nay use advertising, special promotional programs, or offer additional :ervices with his product. Since an effective sales program may increase he sales of one seller at the expense of lower sales for other sellers in he market, we usually find that each seller develops a sales program of his own to offset the effect of a sales program used by his competitors.

The promotional program used in this study offered gratuitous inormation and service to consumers who would contact nurseries. During 
the study, prices of ornamentals sold by cooperating nurseries remained stable. Nurseries not familiar with the purpose of the promotional program may have assumed that the cooperating nurseries were increasing their emphasis on non-price competition. If this was the case one would expect nurseries not participating in the project to also increase their emphasis on non-price competition in order to prevent losing part of their sales to nurseries using the experimental promotional program.

There are data which suggest that nonparticipating nurseries did enter the experimental and control areas during the experiment and offered gratuitous information and service similar to that offered by cooperating nurseries. In a station bulletin pertaining to this same study Pease made the following statement, "The data suggest that in City A some other nursery had competed with the cooperating concem in obtaining patronage by the performance of free services, and that City A's homeowner responses [in terms of expenditures] might give an erroneous impression of the impact of the experimental trials" (6).

Responses obtained in the recall phase of the follow-up interviews in Pennsylvania suggest that some homeowners were not clear as to which nursery had provided the promotional program offering gratuitous information and service. In the follow-up interviews the respondents residing in experimental and control areas were asked whether or not any nursery representatives called at their home within the past twelve months to leave information or talk about trees or shrubs. The 235 respondents who answered in the affirmative were then asked to give names of the nurseries which were represented. In the experimenta areas 49 respondents recalled names of cooperating nurseries, 45 recallec names of other nurseries, and 62 did not recall the name of the nursery represented. In the control areas 11 respondents recalled names of co operating nurseries, 32 recalled names of other nurseries, and 36 did no recall the name of the nursery represented (7).

During the follow-up interviews in Pemsylvania the respondent who recalled a nursery representative contacting them during the pas twelve months were asked, "What do you recall about the purpose of th contact?" In the experimental areas, 36 respondents who recalled name of cooperating nurseries, 31 who recalled names of other nurseries, an 29 who did not recall the name of the nursery represented, mentione items related to the purpose of the promotional program. In the contre areas, 2 who recalled names of cooperating nurseries, 22 who recalle names of other nurseries, and 17 who did not recall the name of th nursery represented. mentioned items related to the purpose of the pro motional program (7). 
The preceding discussion indicates that the ornamental market does not meet the requirements of pure competition. The data presented suggest that the ornamental market is restricted in size, has few sellers relative to number of potential buyers, sells products which are differentiated in the consumers' minds, and uses non-price competition. These are the characteristics of an oligopolistic market structure.

If the ornamental market structure is an oligopoly, that fact is helpful in explaining the small influence that the offer of gratuitous information and service had on increasing dollar sales of ornamental products and on producing a significant change in consumer attitudes toward aurseries and landscaping.

\section{Literature Cited}

1. U.S. Bureau of the Census. U.S. Census of Agriculture: 1959. Vol. V Special Reports, Part I.-Horticultural Specialities. Washington: Government Printing Office, 1962.

2. Pease, Roger W., Consumer Purchases and Preferences in Landscaping. IV. Va. Univ. Agr. Exp. Sta. Bull. 462, 1961.

3. Kivlin, Joseph and C. A. Becker, Factors Influencing Homeowner Use of Ornamental Nursery Products. Pa. State Univ. Agr. Exp. Sta. Bull. 637, 1958.

4. Pease, Roger IV., Marketing of Ornamental Shrubs and Trees by West Virginia Nurseries. IV. Va. Univ. Agr. Exp. Sta. Bull. 417, 1958.

5. Metz, Joseph F. Jr., and H. Royce Gully, Retailing Nursery Products. Dept. of Agr. Econ., Cornell Univ., A. E. Res. 22, 1959.

6. Pease, Roger W., Ornamentals-Consumer Response to 1. Distribution of Literature 2. A Free Landscape Sketching Service. W. Va. Univ. Agr. Exp. Sta.
Bull. 491, 1964 .

7. Eyerly, Raymond Werner, Development of and Consumer Response to an Information Merchandising Technique for Ornamental Nursery Products. Unpublished M.S. thesis, Pa. State Univ., 1963. 



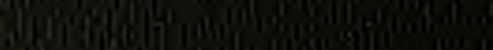

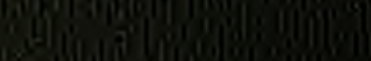

(1)

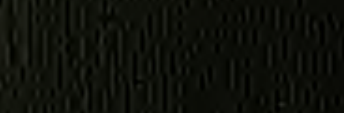

in

(1)

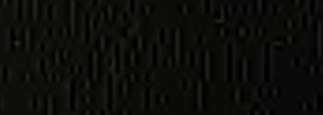

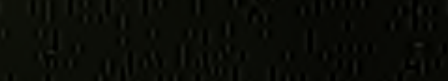

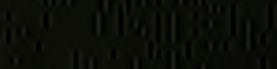

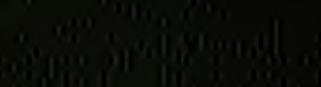

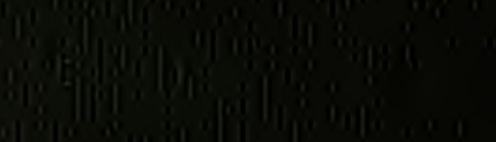

(3)

and 